\title{
The Monolinguistic Approach in Learning to Read
}

\author{
JULIETA B. HERMOSILLA \\ http://orcid.org/0000-0002-8661-741X \\ julietahermosilla77@gmail.com
}

\begin{abstract}
The research study was done to obtain information from two Kindergarten classes as variables; one class was taught in English, the other, in Bisaya. The effectiveness of language used in learning to read was assessed after explaining different components of reading. This study utilized a quasi-experimental research method that discovered the influence of controlled conditions, of experimental and manipulated variables. Fiftyfour kindergarten pupils of San Pablo Elementary School were the subjects of the study. The results were treated statistically using the mean and two non-parametric tools namely, the Mann-Whitney $U$ test and the Wilcoxon signed rank test to test the significant differences between the two groups and within groups. The data showed an increase in the reading skills of the learners in both classes. This result further implied that there was no significant difference in the usage of English or Bisaya in teaching. Learners, from both classes, were able to learn the concepts presented to them though there was scarcity in instructional materials and other supplemental resources. Using the mother tongue in the classroom did not affect their proficiency and that they were able to perform the skills in reading and this is also true among those in the English group. Thus, it can be concluded that the use of the medium of instruction in the classroom was not a barrier to the teaching of early learners. Be it in English or Bisaya, the results were just comparable and that both languages could be used as a medium of instruction in learning how to read among the young learners.
\end{abstract}


Keywords: Medium of instruction, mother tongue, quasi-experimental method, Mann-Whitney $U$, Wilcoxon, reading, young learners

\section{INTRODUCTION}

Reading holds the key to the child's future. It admits him into the world of great thoughts, fancy, and wild imagination (Villamin, 1984). But an alarming number of learners failed to make satisfactory progress and performance in learning to read in the first grade. They achieve poorly in their academic subjects, and tendencies for others to drop-out because they were not able to understand the language of teaching and the instruction, especially during the examination period.

In this world of competitiveness, parents, teachers and even policymakers want all learners of all ages to be aggressive competitors. However, the educational system in our country needs an exhaustive study and readjustment. Meeting the demands of quality, globalized education will take years of hard work, not to mention financial support from the government.

Furthermore, the discussion about the reading program has been a problem in the Philippines for many years. Thus, educators and policymakers today face the challenge of capacity to read among a growing number of students. One of those is using an appropriate medium of instruction in teaching reading, either in English and Filipino or the child's mother tongue or vernacular. It usually revolves around the question of the appropriate language of instruction to use for learners who speak more than one language.

Historically, English was introduced in the Philippines in 1898 during the imposition of American rule on the islands. In the last quarter of the century, English has been used as a medium of instruction alongside the national language, now known as Filipino. The need to be proficient in the use of English among non-native speakers has become a global phenomenon. Moreover, using English as a medium of instruction will not only make children proficient academically but also compete globally. Thus, former President Gloria Macapagal-Arroyo issued Executive Order No. 210 Series of 2003 establishing a policy to strengthen the use of English language as a medium of instruction in the educational system.

The Philippine Committee on Education Reform also suggested the use of the vernacular or the child's first language as a bridge to more effective 
learning in Filipino and English as well as to facilitate cognitive maturity (Nolasco, 2010). Furthermore, the language of instruction, especially in the mother tongue, is the easiest and fastest way of learning the skills in learning to read since it is the language use at home in which the learners are familiar. In connection with this, DepEd Order 74 series of 2009, Institutionalizes Mother Tongue-Based MLE using more than two languages for literacy and instruction is the fundamental policy of the program which stretched the whole formal education including preschool. The strategy was to develop the cognitive skills of the learner in their First Language and transfer these skills in their Second Language later.

This study presented the effectiveness and the significant differences of the languages used which are English and Bisaya, in teaching and learning children to read and improve the reading performance that would help them achieve their goals in life and develop their full potential to be a successful learner.

\section{METHODOLOGY}

This study utilized a quasi-experimental research method that discovered the influence of controlled conditions, of experimental and manipulated variables. The study investigated the effects of the instruction used in the classroom in reading performance of young children after being exposed to English and Bisaya instruction.

The kindergarten pupils of San Pablo Elementary School were the subjects of the study. The table below shows the population of learners enrolled for the school year $2012-2013$.

Table 1. Subjects of the study

\begin{tabular}{|c|c|c|c|c|c|}
\hline Session & Instruction Used & Male & Female & Total & Percentage \\
\hline A.M. & English & 11 & 18 & 29 & $54 \%$ \\
\hline P.M. & Bisaya & 15 & 10 & 25 & $46 \%$ \\
\hline \multicolumn{3}{|r|}{} & \multicolumn{2}{c|}{$\mathrm{N}=100 \%$} \\
\hline
\end{tabular}

In gathering the information, the researcher used the teacher-made test based on the competencies of Kindergarten Reading using English and Bisaya instruction. The researcher was advised to make the lesson guide in Reading which covered reading skills taught in the first and second quarters. This guide in Reading was the basis for preparing the assessment 
tools that was administered first to the grade one learners to test the validity of the tools.

The lessons were administered for the first and second quarters which were assessed in every quarter. The assessment results were tabulated and evaluated to find out which skills had been mastered by the learners using English and Bisaya instruction. After the lessons had been conducted, the 30 item teacher-made tests using the two different media of instructions were administered. The results were treated statistically using the mean and two non-parametric tools namely, the Mann-Whitney $U$ test and the Wilcoxon signed rank test to test the significant differences between the two groups and within groups.

\section{RESULTS AND DISCUSSION}

As to the levels of performance among kindergarten in English and Bisaya groups in the two grading periods concerning phonemic awareness, word recognition, and word comprehension, Table 2 illustrates the findings.

Table 2. Level of performance among kindergarten learners using English as medium of instruction.

\begin{tabular}{|c|c|c|c|c|c|c|c|c|c|}
\hline \multirow[b]{2}{*}{$\begin{array}{l}\text { Reading } \\
\text { Skills }\end{array}$} & \multirow{2}{*}{$\begin{array}{c}\text { Total } \\
\text { Number } \\
\text { of Items }\end{array}$} & \multicolumn{3}{|c|}{ First Grading Period } & \multirow[b]{2}{*}{$\begin{array}{l}\text { Level } \\
\text { of } \\
\text { Profi- } \\
\text { ciency }\end{array}$} & \multirow{2}{*}{\multicolumn{3}{|c|}{$\begin{array}{c}\text { Second Grading Period } \\
\text { Number of Learners who Failed/ } \\
\text { Passed the } 75 \% \text { Criterion of the } \\
30-\text { item test }\end{array}$}} & \multirow[b]{2}{*}{$\begin{array}{l}\text { Level of } \\
\text { Profi- } \\
\text { ciency }\end{array}$} \\
\hline & & \multicolumn{3}{|c|}{$\begin{array}{l}\text { Number of Learners who Failed/ } \\
\text { Passed the } 75 \% \text { Criterion of the } \\
\quad 30-\text { item test }\end{array}$} & & & & & \\
\hline \multirow{2}{*}{$\begin{array}{l}\text { Phonemic } \\
\text { Awareness }\end{array}$} & \multirow[b]{2}{*}{$n=10$} & Failed & 7 & \multirow{2}{*}{$\begin{array}{l}\bar{x}=8.74 \\
(87.4 \%)\end{array}$} & \multirow[b]{2}{*}{$P$} & Failed & 2 & \multirow{2}{*}{$\begin{array}{c}\bar{x}=9.12 \\
(91.2 \%)\end{array}$} & \multirow[b]{2}{*}{ A } \\
\hline & & Passed & 22 & & & Passed & 27 & & \\
\hline \multirow{2}{*}{$\begin{array}{l}\text { Word Re- } \\
\text { cognition }\end{array}$} & \multirow[b]{2}{*}{$\mathrm{n}=10$} & Failed & 4 & \multirow{2}{*}{$\begin{array}{c}\bar{x}=9.07 \\
(90.7 \%)\end{array}$} & \multirow[b]{2}{*}{ A } & Failed & 3 & \multirow{2}{*}{$\begin{array}{c}\bar{x}=9.41 \\
(94.1 \%)\end{array}$} & \multirow[b]{2}{*}{ A } \\
\hline & & Passed & 25 & & & Passed & 26 & & \\
\hline \multirow{2}{*}{$\begin{array}{l}\text { Word Com- } \\
\text { prehension }\end{array}$} & \multirow[b]{2}{*}{$\mathrm{n}=10$} & Failed & 15 & \multirow{2}{*}{$\begin{array}{c}\bar{x}=6.66 \\
(66.6 \%)\end{array}$} & \multirow{2}{*}{ B } & Failed & 10 & \multirow{2}{*}{$\begin{array}{c}\bar{x}=7.83 \\
(78.3 \%)\end{array}$} & \multirow[b]{2}{*}{ D } \\
\hline & & Passed & 14 & & & Passed & 19 & & \\
\hline \multirow[b]{2}{*}{ Totality } & \multirow[b]{2}{*}{$\mathrm{n}=\mathbf{3 0}$} & Failed & 9 & \multirow{2}{*}{$\begin{array}{c}\bar{x}=24.47 \\
(81.57 \%)\end{array}$} & \multirow[b]{2}{*}{ AP } & Failed & 5 & \multirow{2}{*}{$\begin{array}{c}\bar{x}=26.36 \\
(87.87 \%)\end{array}$} & \multirow[b]{2}{*}{$\mathbf{P}$} \\
\hline & & Passed & 20 & & & Passed & 24 & & \\
\hline
\end{tabular}

Legend: Level of Proficiency (Based on Department of Education's Grading System)

$\begin{array}{ll}\text { Beginning } & \text { (B: } 74 \% \text { and below) } \\ \text { Developing } & \text { (D: } 75 \%-79 \%) \\ \text { Approaching Proficiency } & \text { (AP: } 80 \%-84 \%) \\ \text { Proficient } & \text { (P: } 85 \%-89 \%) \\ \text { Advanced } & \text { (A: } 90 \% \text { and above) }\end{array}$


Table 3: Level of performance among kindergarten learners using Bisaya as the medium of instruction.

\begin{tabular}{|c|c|c|c|c|c|c|c|c|c|}
\hline \multirow{4}{*}{$\begin{array}{c}\begin{array}{c}\text { Reading } \\
\text { Skills }\end{array} \\
\text { Phonemic } \\
\text { Awareness }\end{array}$} & \multirow{2}{*}{$\begin{array}{l}\text { Total } \\
\text { Num- } \\
\text { ber of } \\
\text { Items }\end{array}$} & \multirow{2}{*}{\multicolumn{3}{|c|}{$\begin{array}{c}\text { First Grading Period } \\
\text { Number of Learners who Failed } \\
\text { Passed the } 75 \% \text { Criterion of the } \\
30-\text { item test }\end{array}$}} & \multirow{2}{*}{$\begin{array}{l}\text { Level } \\
\text { of } \\
\text { Profi- } \\
\text { ciency }\end{array}$} & \multirow{2}{*}{\multicolumn{3}{|c|}{$\begin{array}{c}\text { Second Grading Period } \\
\text { Number of Learners who Failed/ } \\
\text { Passed the } 75 \% \text { Criterion of the } \\
\quad 30-\text { item test }\end{array}$}} & \multirow{2}{*}{$\begin{array}{l}\text { Level } \\
\text { of } \\
\text { Profi- } \\
\text { ciency }\end{array}$} \\
\hline & & & & & & & & & \\
\hline & \multirow[b]{2}{*}{$\mathrm{n}=10$} & Failed & 6 & \multirow[b]{2}{*}{$\bar{x}=8.78(87.8 \%)$} & \multirow[b]{2}{*}{$P$} & Failed & 0 & \multirow[b]{2}{*}{$\bar{x}=9.52(95.2 \%)$} & \multirow[b]{2}{*}{$A$} \\
\hline & & Passed & 19 & & & Passed & 25 & & \\
\hline \multirow{2}{*}{$\begin{array}{l}\text { Word Re- } \\
\text { cognition }\end{array}$} & \multirow[b]{2}{*}{$\mathrm{n}=10$} & Failed & 0 & \multirow[b]{2}{*}{$\bar{x}=9.36(93.6 \%)$} & \multirow[b]{2}{*}{ A } & Failed & 1 & \multirow[b]{2}{*}{$\bar{x}=9.56(95.6 \%)$} & \multirow[b]{2}{*}{$A$} \\
\hline & & Passed & 25 & & & Passed & 24 & & \\
\hline \multirow{2}{*}{$\begin{array}{l}\text { Word Com- } \\
\text { prehension }\end{array}$} & \multirow[b]{2}{*}{$\mathrm{n}=10$} & Failed & 13 & \multirow[b]{2}{*}{$\bar{x}=7.04(70.4 \%)$} & \multirow[b]{2}{*}{ B } & Failed & 5 & \multirow[b]{2}{*}{$\bar{x}=8.20(82.0 \%)$} & \multirow[b]{2}{*}{ AP } \\
\hline & & Passed & 12 & & & Passed & 20 & & \\
\hline \multirow[b]{2}{*}{ Totality } & \multirow[b]{2}{*}{$n=30$} & Failed & 6 & \multirow[b]{2}{*}{$\bar{x}=25.18(83.93 \%)$} & \multirow[b]{2}{*}{ AP } & Failed & 3 & \multirow[b]{2}{*}{$\bar{x}=27.28(90.93 \%)$} & \multirow[b]{2}{*}{$A$} \\
\hline & & Passed & 19 & & & Passed & 22 & & \\
\hline
\end{tabular}

Legend: Level of Proficiency (Based on Department of Education's Grading System)

Beginning

Developing

Approaching Proficiency

Proficient

Advanced
(B: $74 \%$ and below)

(D: $75 \%-79 \%)$

(AP: $80 \%-84 \%$ )

(P: $85 \%-89 \%)$

(A: $90 \%$ and above)

The English Group (Table 2) and Bisaya Group (Table 3) showed increased performance in the three reading skills after conducting the two grading periods. This result proved Krashen's (1982) theory on language acquisition in which he argued that learners acquire foreign languages on basically the same path they acquired their mother tongue.

Both groups of learners mastered the sounds and the awareness of the phonemics and the letters which made it easy for them to distinguish, identify, and discriminate through letter perception. Phonemic awareness and letter knowledge had been identified in several research studies (Anderson, Hiebert, Scott, and Wilkerson, 1988; Adams, 1990; Snow, Burns, \& Griffin, 1998) as the key indicators of how well children master beginning reading skills during the first two years in school. Thus the development of solid phonemic awareness skills should be the main goal of the preschool and kindergarten years.

It can be gleaned that both groups had recognized the words that manifested mastery of the letter sounds and helped learners blend the sounds so that they would be able to read and attack words. The activities help the learners improved their performance in learning how to read. In connection to this, the study made by Amamio (2000) on the attitudes of the students, teachers and parents toward English and Filipino as media of instruction provided an interesting comparison in which students and teachers prefer the use of English as the medium of instruction, with the 
teachers finding English as a more comfortable language for explaining ideas and concepts. The lessons they have undergone helped them to learn and cope when they were enrolled in kindergarten.

From the level of difficulty to a bit difficult was the development of the vocabulary skills. The drills and exercises were at learners' level, from learning the sounds of the letters to reading CV (consonant-vowel) and CVC (consonant-vowel-consonant) in which learners were able to identify and read the words presented to them. Thus, beginner readers must be able to make the connection that words are made up of sounds, and that sounds are made up of letters and letter combinations (Gunning, 1996). This understanding is the foundation on which to build solid reading skills.

\section{Significant mean difference between the English and Bisaya group in terms of their reading performance}

Table 4. Mean difference between the English and Bisaya group in terms of reading performance.

\begin{tabular}{|c|c|c|c|c|c|c|c|}
\hline Period & Reading Skills & $\begin{array}{c}\text { Mean of English } \\
\text { Group }\end{array}$ & $\begin{array}{c}\text { Mean of } \\
\text { Bisaya Group }\end{array}$ & $\begin{array}{c}\text { Mean } \\
\text { Difference }\end{array}$ & $\begin{array}{c}\text { Mann- } \\
\text { Whitney } \\
\text { U value }\end{array}$ & $\begin{array}{c}p- \\
\text { value }\end{array}$ & Interpretation \\
\hline \multirow{4}{*}{$\begin{array}{c}\text { First } \\
\text { Grading } \\
\text { Period }\end{array}$} & $\begin{array}{l}\text { Phonemic } \\
\text { Awareness }\end{array}$ & $\begin{array}{c}8.74 \\
(87.4 \%-P)\end{array}$ & $\begin{array}{c}8.78 \\
(87.8 \%-P)\end{array}$ & 0.04 & 360.5 & 0.970 & $\begin{array}{c}\text { Not } \\
\text { significant }\end{array}$ \\
\hline & $\begin{array}{c}\text { Word } \\
\text { Recognition }\end{array}$ & $\begin{array}{c}9.07 \\
(90.7 \%-A)\end{array}$ & $\begin{array}{c}9.36 \\
(93.6 \%-A)\end{array}$ & 0.29 & 323.5 & 0.460 & $\begin{array}{c}\text { Not } \\
\text { significant }\end{array}$ \\
\hline & $\begin{array}{c}\text { Word } \\
\text { Comprehension }\end{array}$ & $\begin{array}{c}6.66 \\
(66.6 \%-B)\end{array}$ & $\begin{array}{c}7.04 \\
(70.4 \%-B)\end{array}$ & 0.38 & 333.5 & 0.611 & $\begin{array}{c}\text { Not } \\
\text { significant }\end{array}$ \\
\hline & Totality & $\begin{array}{c}24.47 \\
(81.57 \%-A P)\end{array}$ & $\begin{array}{c}25.18 \\
(83.93 \%-A P)\end{array}$ & 0.71 & 333.0 & 0.608 & Not significant \\
\hline \multirow{4}{*}{$\begin{array}{l}\text { Second } \\
\text { Grading } \\
\text { Period }\end{array}$} & $\begin{array}{l}\text { Phonemic } \\
\text { Awareness }\end{array}$ & $\begin{array}{c}9.12 \\
(91.2 \%-A)\end{array}$ & $\begin{array}{c}9.52 \\
(95.2 \%-A)\end{array}$ & 0.40 & 317.5 & 0.411 & $\begin{array}{c}\text { Not } \\
\text { significant }\end{array}$ \\
\hline & $\begin{array}{c}\text { Word } \\
\text { Recognition }\end{array}$ & $\begin{array}{c}9.41 \\
(94.1 \%-A)\end{array}$ & $\begin{array}{c}9.56 \\
(95.6 \%-A)\end{array}$ & 0.15 & 337.0 & 0.565 & $\begin{array}{c}\text { Not } \\
\text { significant }\end{array}$ \\
\hline & $\begin{array}{c}\text { Word } \\
\text { Comprehension }\end{array}$ & $\begin{array}{c}7.83 \\
(78.3 \%-D)\end{array}$ & $\begin{array}{c}8.20 \\
(82.0 \%-A P)\end{array}$ & 0.37 & 309.5 & 0.347 & $\begin{array}{c}\text { Not } \\
\text { significant }\end{array}$ \\
\hline & Totality & $\begin{array}{c}26.36 \\
(87.87 \%-\mathrm{P})\end{array}$ & $\begin{array}{c}27.28 \\
(90.93 \%-A)\end{array}$ & 0.92 & 313.5 & 0.392 & Not significant \\
\hline
\end{tabular}

Legend: Level of Proficiency (Based on Department of Education's Grading System)

$\begin{array}{ll}\text { Beginning } & \text { (B: } 74 \% \text { and below) } \\ \text { Developing } & \text { (D: } 75 \%-79 \%) \\ \text { Approaching Proficiency } & \text { (AP: } 80 \%-84 \%) \\ \text { Proficient } & \text { (P: } 85 \%-89 \%) \\ \text { Advanced } & \text { (A: } 90 \% \text { and above) }\end{array}$

The Reading performance both in English and Bisaya Groups is comparable in the first and second grading periods. Goodman (1993) 
agreed that learning to read is an extension of existing language skills and that it is important to understand the written language in the same way as the spoken language is learned. Furthermore, emergent literacy of Clay (1975) explained that when children are actively engaged with interesting and meaningful reading and writing experiences, they develop literacy knowledge early in their lives. The media of instruction used were of the same level and that both languages, English and Bisaya can be used as a media of instruction in teaching and learning how to read.

\section{Significant mean gain between the first and second grading periods between the English and Bisaya groups}

Table 5: The level of performance between the first and second grading period among the English and Bisaya groups.

\begin{tabular}{|c|c|c|c|c|c|c|c|}
\hline Groups & $\begin{array}{l}\text { Reading } \\
\text { Skills }\end{array}$ & $\begin{array}{c}\text { First Grading } \\
\text { Mean }\end{array}$ & $\begin{array}{l}\text { Second Gra- } \\
\text { ding Mean }\end{array}$ & $\begin{array}{c}\text { Mean } \\
\text { Gain }\end{array}$ & $\begin{array}{l}\text { Wilcoxon } \\
\text { Computed z }\end{array}$ & $p$ - value & Interpretation \\
\hline \multirow{4}{*}{$\begin{array}{l}\text { English } \\
\text { Group }\end{array}$} & $\begin{array}{l}\text { Phonemic } \\
\text { Awareness }\end{array}$ & $\begin{array}{c}8.74 \\
(87.4 \%-P)\end{array}$ & $\begin{array}{c}9.12 \\
(91.2 \%-A)\end{array}$ & 0.38 & 1.434 & 0.152 & Not improved \\
\hline & $\begin{array}{c}\text { Word Recog- } \\
\text { nition }\end{array}$ & $\begin{array}{c}9.07 \\
(90.7 \%-A)\end{array}$ & $\begin{array}{c}9.41 \\
(94.1 \%-A)\end{array}$ & 0.34 & 1.364 & 0.173 & Not improved \\
\hline & $\begin{array}{c}\text { Word Compre- } \\
\text { hension }\end{array}$ & $\begin{array}{c}6.66 \\
(66.6 \%-B)\end{array}$ & $\begin{array}{c}7.83 \\
(78.3 \%-\mathrm{D})\end{array}$ & 1.17 & 2.507 & 0.012 & Improved \\
\hline & Totality & $\begin{array}{c}24.47 \\
(81.57 \%-\text { AP) }\end{array}$ & $\begin{array}{c}26.36 \\
(87.87 \%-\mathrm{P})\end{array}$ & 1.89 & 2.653 & 0.008 & Improved \\
\hline \multirow{4}{*}{$\begin{array}{l}\text { Bisaya } \\
\text { Group }\end{array}$} & $\begin{array}{l}\text { Phonemic } \\
\text { Awareness }\end{array}$ & $\begin{array}{c}8.78 \\
(87.8 \%-P)\end{array}$ & $\begin{array}{c}9.52 \\
(95.2 \%-A) \\
\end{array}$ & 0.74 & 2.727 & 0.006 & Improved \\
\hline & $\begin{array}{c}\text { Word Recog- } \\
\text { nition }\end{array}$ & $\begin{array}{c}9.36 \\
(93.6 \%-A)\end{array}$ & $\begin{array}{c}9.56 \\
(95.6 \%-A)\end{array}$ & 0.20 & 1.232 & 0.218 & Not Improved \\
\hline & $\begin{array}{l}\text { Word Compre- } \\
\text { hension }\end{array}$ & $\begin{array}{c}7.04 \\
(70.4 \%-B)\end{array}$ & $\begin{array}{c}8.20 \\
(82.0 \%-\mathrm{AP})\end{array}$ & 1.16 & 2.445 & 0.014 & Improved \\
\hline & Totality & $\begin{array}{c}25.18 \\
(83.93 \%-\text { AP) }\end{array}$ & $\begin{array}{c}27.28 \\
(90.93 \%-A)\end{array}$ & 2.10 & 2.973 & 0.003 & Improved \\
\hline
\end{tabular}

Legend: Level of Proficiency (Based on Department of Education's Grading System)

Beginning

Developing

Approaching Proficiency

Proficient

Advanced
(B: $74 \%$ and below)

(D: $75 \%-79 \%$ )

(AP: $80 \%-84 \%$ )

(P: $85 \%-89 \%)$

(A: $90 \%$ and above)

The totality of both groups, English and Bisaya, showed an improvement since the researcher who handled the two groups used the common lessons and exercises for practice and drill content exposure. The learning of the production of phonemes has improved the skills of the learners and their experiences through listening and in print have enriched and added those words in their vocabulary. Proper sequencing strengthens children's 
children's learning (Dekker, 2002). Learning to read is most efficient when learners know the language and can employ psycholinguistic guessing strategies. Likewise, learners can communicate through writing as soon as they understand the rules of the orthographic (or other written) system of their language. Moreover, mother tongue-based bilingual education not only increases access to skills but also raises the quality of basic education by facilitating classroom interaction and integration of prior knowledge and experiences with new learning (Benson, 2004). Additionally, Kang (2012) in her study "English - only Instruction at Korean Universities: Help or hindrance to Higher Learning," concluded that using the first language for at least some of the instructional time helped learners achieved the content learning process as well as second language and literacy development because it allowed them to transfer their cognitive and meta-cognitive skills from their first language to a second language. Thus, learners of both groups responded to the lessons positively.

\section{Mean gain difference between English and Bisaya group in terms of their reading performance}

\begin{tabular}{|c|c|c|c|c|c|c|c|c|}
\hline \multirow{2}{*}{$\begin{array}{c}\text { Reading } \\
\text { Skills }\end{array}$} & \multirow{2}{*}{$\begin{array}{c}\text { Grading } \\
\text { Period }\end{array}$} & \multicolumn{2}{|c|}{ English Group } & \multicolumn{2}{|c|}{ Bisaya Group } & \multirow{2}{*}{$\begin{array}{c}\text { Mann- } \\
\text { Whitney } \\
\text { u - value }\end{array}$} & \multirow{2}{*}{$\begin{array}{c}\text { p - } \\
\text { value }\end{array}$} & \multirow{2}{*}{$\begin{array}{l}\text { Interpreta- } \\
\text { tion }\end{array}$} \\
\hline & & Mean & Gain & Mean & Gain & & & \\
\hline \multirow{2}{*}{$\begin{array}{c}\text { Pho- } \\
\text { nemic } \\
\text { Aware- } \\
\text { ness }\end{array}$} & $\begin{array}{c}\text { First } \\
\text { Grading }\end{array}$ & $\begin{array}{c}8.74 \\
(87.4 \%-P)\end{array}$ & \multirow[t]{2}{*}{0.38} & $\begin{array}{c}8.78 \\
(87.8 \%-P)\end{array}$ & \multirow[t]{2}{*}{0.74} & \multirow[t]{2}{*}{309.5} & \multirow[t]{2}{*}{0.338} & \multirow{2}{*}{$\begin{array}{c}\text { Not } \\
\text { Significantly } \\
\text { Different }\end{array}$} \\
\hline & $\begin{array}{l}\text { Second } \\
\text { Grading }\end{array}$ & $\begin{array}{c}9.12 \\
(91.2 \%-A)\end{array}$ & & $\begin{array}{c}9.52 \\
(95.2 \%-A)\end{array}$ & & & & \\
\hline \multirow{2}{*}{$\begin{array}{l}\text { Word } \\
\text { Recog- } \\
\text { nition }\end{array}$} & $\begin{array}{c}\text { First } \\
\text { Grading } \\
\end{array}$ & $\begin{array}{c}9.07 \\
(90.7 \%-A)\end{array}$ & \multirow[t]{2}{*}{0.34} & $\begin{array}{c}9.36 \\
(93.6 \%-A) \\
\end{array}$ & \multirow[t]{2}{*}{0.20} & \multirow[t]{2}{*}{310.0} & \multirow[t]{2}{*}{0.322} & \multirow{2}{*}{$\begin{array}{c}\text { Not } \\
\text { Significantly } \\
\text { Different }\end{array}$} \\
\hline & $\begin{array}{l}\text { Second } \\
\text { Grading }\end{array}$ & $\begin{array}{c}9.41 \\
(94.1 \%-A)\end{array}$ & & $\begin{array}{c}9.56 \\
(95.6 \%-A)\end{array}$ & & & & \\
\hline \multirow{2}{*}{$\begin{array}{l}\text { Word } \\
\text { Compre- } \\
\text { hension }\end{array}$} & $\begin{array}{c}\text { First } \\
\text { Grading }\end{array}$ & $\begin{array}{c}6.66 \\
(66.6 \%-B)\end{array}$ & \multirow[t]{2}{*}{1.17} & $\begin{array}{c}7.04 \\
(70.4 \%-B)\end{array}$ & \multirow[t]{2}{*}{1.16} & \multirow[t]{2}{*}{361.5} & \multirow[t]{2}{*}{0.986} & \multirow{2}{*}{$\begin{array}{c}\text { Not } \\
\text { Significantly } \\
\text { Different }\end{array}$} \\
\hline & $\begin{array}{l}\text { Second } \\
\text { Grading }\end{array}$ & $\begin{array}{c}7.83 \\
(78.3 \% \text { - D) }\end{array}$ & & $\begin{array}{c}8.20 \\
(82.0 \%-A P)\end{array}$ & & & & \\
\hline \multirow[t]{2}{*}{ Totality } & $\begin{array}{l}\text { First } \\
\text { Grading }\end{array}$ & $\begin{array}{c}24.47 \\
(81.57 \%-A P)\end{array}$ & \multirow[t]{2}{*}{1.89} & $\begin{array}{c}25.18 \\
(83.93 \%- \\
\text { AP) }\end{array}$ & \multirow[t]{2}{*}{2.10} & \multirow[t]{2}{*}{329.0} & \multirow[t]{2}{*}{0.559} & \multirow{2}{*}{$\begin{array}{c}\text { Not } \\
\text { Significantly } \\
\text { Different }\end{array}$} \\
\hline & $\begin{array}{l}\text { Second } \\
\text { Grading }\end{array}$ & $\begin{array}{c}26.36 \\
(87.87 \%-P)\end{array}$ & & $\begin{array}{c}27.28 \\
(90.93 \%-A)\end{array}$ & & & & \\
\hline
\end{tabular}

Legend: Level of Proficiency (Based on Department of Education's Grading System)

Beginning

Developing

Approaching Proficiency

Proficient

Advanced
(B: $74 \%$ and below)

(D: $75 \%-79 \%$ )

(AP: $80 \%-84 \%$ )

(P: $85 \%-89 \%$ )

(A: $90 \%$ and above) 
There was no significant difference in using both English and Bisaya as the media of instruction in teaching and learning how to read. As stated in Krashen's (2002) theory, learners acquire foreign languages, on the same path, they acquired their mother tongue. Learners were able to understand and answer the questions with good and passing marks since both groups were taught either in English or Bisaya. This finding was contradicted by Prodromou's (2000) study in which it was concluded that the more English students learn, the less reliant they are on the L1 and that, as a whole, the students seem to have a negative opinion of $L 1$ use in the classroom. Thus, the mother tongue will not only improve the quality of education, but it may also be the tool for learning and improving English (Netten, Droop, and Verhoeven, 2010).

\section{CONCLUSION}

The use of the medium of instruction was not a barrier to the teaching and learning of reading for the young learners using the second language or the mother tongue. And that both English and Bisaya did not vary in learning how to read having limited instructional materials using Bisaya as the language of instruction. There was a comparable result with that of the English instruction.

\section{REFERENCES CITED}

Adams, M. J. (1990. Beginning to read: Thinking and Learning About Print. Cambridge, MA. MIT Press.

Amamio, L. (2000. "Attitudes of Students, Teachers and Parents of RVM Schools in Metro Manila Toward English and Filipino as Media of Instruction."

Anderson, R. C., Hiebert, E. H., Scott, J. A., Wilkinson, I. A., Becker, W., \& Becker, W. C. (1988). Becoming a nation of readers: The report of the Commission on Reading. Education and Treatment of Children, 389396. Retrieved from https://goo.gl/EYBkXv, (accessed last 15 January 2016). 
Benson, C., (2004). "The Importance of Mother Tongue-Based Schooling for Educational Quality." Stockholm University.

Clay, M.M., (1975). What did I write? Beginning Writing Behaviour. Auckland, NZ.

Dekker, D. E., (2002). A Case Study of the First Language Component Bridging Program in Rural Philippines.

Goodman, K. (1993). Phonics Phacts. Portsmouth: Heinemann.

Gunning, T.G., (1996). Word building: A Strategic Approach to the Teaching of Phonics. The Reading Teacher. pp. 484-488. Retrieved from https:// goo.gl/qdm9tp, (accessed last 21 January 2016).

Kang, H. (2012). "English-only instruction at Korean universities: Help or hindrance to higher learning?" English Today, 28(1), 29-34. Retrieved from https://goo.gl/Bqs1ao, (accessed last 5 January 2016).

Krashen, S.D. (1982). Principles and Practice in Second Language Acquisition.

Netten, A., Droop, M., \& Verhoeven, L. (2011). Predictors of reading literacy for first and second language learners. Reading and writing, 24(4), 413425. Retrieved from https://goo.gl/shr33e, (accessed last 30 December 2015).

Nolasco, R. M. D. (2010). Filipino, Pilipino and Tagalog. Starting where the children are: a collection of essays on mother tongue-based multilingual education and language issues in the Philippines, 170, 170-172.

Prodromou, L. (2000). From mother tongue to other tongue. TESOL Greece Newsletter, 67, 7-8.

Snow, C., Burns, M., \& Griffin, P. (Eds.), (1998). Preventing reading difficulties in young children. Washington DC: National Academy Press. 
Villamin, Araceli. 1984. Innovative Strategies in Teaching Reading. Quezon City: Phoenix Publishing House, Inc. 